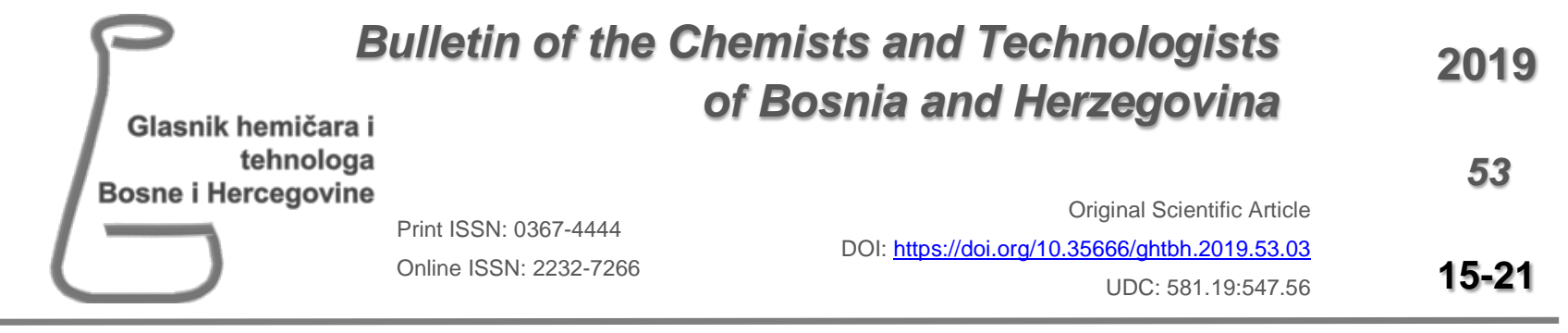

\title{
Phenolics content and antioxidant activity of three Sorbus species
}

\author{
Tahirović, A. ${ }^{a}$, Mehić, E.b, Kjosevski, N. ${ }^{\mathrm{c}}$, Bašić, N. ${ }^{\mathrm{a}}$ \\ ${ }^{a}$ University of Sarajevo, Faculty of Forestry, Department of Forest Ecology, Zagrebačka 20, Sarajevo, B\&H \\ ${ }^{b}$ Džemal Bijedić University of Mostar, Faculty of Education, Department of Chemistry, University campus, \\ Mostar, $B \& H$ \\ 'INSPEKT RGH doo, Hamdije Kreševljakovića 18, Sarajevo, B\&H
}

\section{Article info \\ Received: 17/04/2019 \\ Accepted: 07/10/2019}

Keywords:

Sorbus species

Phenolics

Antioxidant activity

DPPH

ABTS

FRAP

\begin{abstract}
The phenolic content and antioxidant activity of Sorbus aucuparia L., Sorbus aria (L.) Crantz and Sorbus austriaca (Beck) Hedlund leaves and fruit were investigated. The quantification of total phenolics, flavonoids and phenolic acids was performed using the FolinCiocalteu, Dowd and Arnow methods, respectively. The antioxidant activity of the extracts was evaluated using DPPH, TEAC and FRAP methods with Trolox as a standard. Leaves had a higher content of phenolic compounds and antioxidant activity than the fruits for all species. The highest content of phenolics (76.11 mg gallic acid equivalents (GAE)/g plant), flavonoids (15.86 mg rutin equivalents (RE)/g plant) and phenolic acids (44.54 mg caffeic acid equivalents (CAE)/g plant) was determined for $S$. austriaca leaves. Sorbus austriaca fruit had the highest content of phenolics (13.21 mg GAE/g plant), flavonoids (1.82 mg RE/g plant) and S. aucuparia fruit had the highest content of phenolic acids (9.05 mg CAE/g plant). The antioxidant activity was in the range: DPPH=38.42-274.52 $\mu \mathrm{mol}$ Trolox equivalents (TE)/g plant; TEAC=43.23-403.02 $\mu \mathrm{mol} \mathrm{TE} / \mathrm{g}$ plant; FRAP $=47.13-706.96 \mu \mathrm{mol} \mathrm{TE} / \mathrm{g}$ plant. The highest values of antioxidant activity were found for $S$. austriaca leaf and fruit extracts while the lowest values were determined for $S$. aucuparia leaves and S. aria fruit. The antioxidant activity was highly correlated with total phenolics and phenolic acids.
\end{abstract}

*Corresponding author:

Azra Tahirović

E-mail: a.tahirovic@sfsa.unsa.ba

Phone: 00-387-33-812-490

\section{INTRODUCTION}

Sorbus L. genus includes about 250 species of deciduous trees and shrubs mainly widespread in the northern hemisphere (Olszewska and Michel, 2009). It is estimated that about one-third of Sorbus diversity in Europe is located in the Balkan Peninsula, including 18 species and 12 subspecies of the genus (Hajrudinović, SiljakYakovlev, Brown, et al., 2015b and references therein). So far, eight Sorbus species have been recognized in Bosnia and Herzegovina including Sorbus aria (L.) Crantz, Sorbus aucuparia L., and Sorbus austriaca (Beck) Hedl. (Beck-Mannagetta, 1927; Hajrudinović, et al., 2015b). Fruit of S. aucuparia, S. aria, S. domestica and $S$. torminalis have been used for medicinal purposes and as food ingredients in the production of jams and juices. (Mikulić-Petkovsek, Krska, Kiprovski et al., 2017 and references therein). Extracts of leaves, inflorescences, fruit and bark of various Sorbus species are used for their hypoglycaemic, diuretic, vasoprotective, antiinflammatory and antidiarrhoeal properties (Raudoné, Raudonis, Gaivelyte, et al., 2015 and references therein). In particular, inflorescences of $S$. aucuparia are used in traditional and European medicine as a diuretic and antiinflammatory agent. The fruit of $S$. aucuparia and $S$. aria is used as a vitamin and antioxidant agent and for the treatment of diarrhoea (Olszewska and Michel, 2009 and references therein). Some species such as $S$. aucuparia, $S$. aria and $S$. domestica have been identified as possible rich sources of phenolics (Olszsewska and Michel, 2009). The pharmacological properties of Sorbus species have been related to the presence of different phenolic compounds as the main antioxidants (Hukkanen, Pölönen, Kärenlampi, et al., 2006). The presence of polyphenols, 
flavonoids (quercetin derivatives rutin, hyperoside, isoquercitrin), phenolic acids (chlorogenic, neochlorogenic, caffeic acids), proanthocyanidins in leaves and fruit has already been mentioned by several authors (Olszewska, Nowak, Michel, et al., 2010; Gaivelyte, Jakstas, Razukus, et al., 2014; Raudoné, et al., 2015). The fruit is also rich in tocopherols, ascorbic acid, carotenoids and anthocyanins (Mrkonjić, Nađpal, Beara, et al., 2017; Šavikin, Zdunić, Krstić-Milošević, et al., 2017, Mikulić-Petkovsek, et al., 2017 and references therein). Most research on the antioxidant activity of various plant materials has been associated with their application in the food and pharmaceutical industries as a possible source of new natural additives and antioxidants that could replace synthetic ones (Finley, Kong, Hintze, et al., 2011; Surwesvaran, Cai, Corke, et al., 2007). Therefore, the aim of this study was to estimate the phenolic content and antioxidant activity of leaves and fruits of $S$. aucuparia, S. aria and S. austriaca from Bosnia and Herzegovina. Antioxidant activity was estimated using three different methods: DPPH, TEAC and FRAP with Trolox as a standard. The determination of total phenolics, total flavonoids, and total phenolic acids was conducted using the Folin-Ciocalteu, Dowd, and Arnow methods, respectively. Relationships between phenolic compounds and antioxidant activity were investigated. To our knowledge, this is the first report on phenolic content and antioxidant activity of selected Sorbus species from Bosnia and Herzegovina.

\section{EXPERIMENTAL}

All chemicals were of analytical grade. Caffeic acid was purchased from Merck Chemical Suppliers (Germany), and potassium peroxysulfate from Fluka (Germany). Sodium acetate, sodium nitrite and sodium hydroxide were purchased from Kemika, (Croatia), and sodium molybdate from Acros Organics (USA). All other chemicals were obtained from Sigma-Aldrich (Germany).

\section{Plant material}

Leaf and fruit samples of S. aucuparia, S. austriaca and S. aria were collected in October 2016, in the area of Sarajevo, Bosnia and Herzegovina. Samples were identified by a plant taxonomist (one of the authors), and voucher specimens were stored in the Herbarium of Forest Ecology at the Faculty of Forestry. The samples were dried in a ventilated room for 15-20 days, and they were stored in paper bags in a dry and dark place until analysis.

\section{Extraction procedure}

Dried fruits and leaves were pulverised in an electric mill (Gorenje, Slovenia), and then extracted with 80\% ( $/ / v)$ aqueous methanol by ultrasound extraction (Ultrasound bath, Elmasonic, Italy). A modified extraction method previously described by Memon, Memon and Luthria (2010) and Raudonis, et al. (2014) was used. Briefly, plant material $(0.5 \mathrm{~g})$ was extracted twice with $25 \mathrm{~mL}$ of methanol $(80 \%, v / v)$ for 10 minutes at $30^{\circ} \mathrm{C}$. After the centrifugation (3000 rpm, $10 \mathrm{~min}$ ), the resulting supernatants were combined, filtered (Millipore nylon filters, $0.45 \mu \mathrm{m}$ ) in a $50 \mathrm{~mL}$ volumetric flask and supplemented with the extraction medium to the mark. The extracts were stored at $-20^{\circ} \mathrm{C}$ until use. Yields were determined by evaporation of extracts $(5 \mathrm{~mL})$ to dryness.

\section{Determination of total phenolics}

Total phenolics were determined by the Folin-Ciocalteu method as modified and described by Luthria, Mukhopadhyay and Krizek (2004). Sample solution (0.1 $\mathrm{mL})$ was mixed with distilled water $(7.9 \mathrm{~mL})$ and FolinCiocalteu reagent $(500 \mu \mathrm{L})$ was added. After 5 minutes, $\mathrm{Na}_{2} \mathrm{CO}_{3}(20 \%, 1.5 \mathrm{~mL})$ was added, and the total volume was adjusted with distilled water up to $10 \mathrm{~mL}$. Samples were left for 30 minutes at $40^{\circ} \mathrm{C}$ in a water bath (INKO 1935, Zagreb). Absorbance was read at $765 \mathrm{~nm}$ against a blank. Gallic acid was used to prepare the standard curve, and the results were expressed as milligrams of gallic acid equivalents per gram of dry plant (mg GAE/g plant) and per gram of extract (mg GAE/g extract). A Shimadzu UV-mini 1240 spectrophotometer was used for all spectrophotometric determinations.

\section{Determination of total flavonoids}

A modified Dowd method was used to determine total flavonoids as described by Quettier-Deleu, Gressier, Vasseur (2000). Sample solution $(1 \mathrm{~mL})$ and $\mathrm{AlCl}_{3}$ solution ( $2 \%$ in absolute methanol, $1 \mathrm{~mL}$ ) were mixed. The mixture was incubated at room temperature for $1 \mathrm{~h}$, and absorbance was measured at $415 \mathrm{~nm}$ against a blank. The standard curve was prepared with rutin, and the results were expressed as milligrams of rutin equivalents per gram of dry plant (mg RE/g plant) and per gram of extract (mg RE/g extract).

\section{Determination of total phenolic acids}

For the determination of total phenolic acids, the modified Arnow method given by Gawlic-Dziki (2012) was used. Sample solution (1 mL) was mixed with water (5 mL), $\mathrm{HCl}(0.5 \mathrm{M}, 1 \mathrm{~mL})$, Arnow reagent $(1 \mathrm{~mL})$ and $\mathrm{NaOH}(1 \mathrm{M}, 1 \mathrm{~mL})$, followed by the addition of distilled water to a total volume of $10 \mathrm{~mL}$. The samples were incubated for $20 \mathrm{~min}$ at room temperature. Absorbance was measured at $490 \mathrm{~nm}$ against a blank. Total phenolic acids were calculated from the standard curve, and the results expressed as milligrams of caffeic acid equivalents per gram of dry plant (mg CAE/g plant) and per gram of extract (mg CAE/g extract).

\section{2,2-Diphenyl-1-pycrylhydrazyl (DPPH) assay}

Determination of the antioxidant activity with DPPH reagent (2,2-diphenyl-1-pycrylhydrazyl radical) was carried out according to Thaipong, Boonprakob, Crosby (2006). The working solution of DPPH was prepared immediately before measurements by diluting the stock solution ( $3 \mathrm{mM}$ ) to the absorbance of $\mathrm{A}=1.1 \pm 0.02$ at 515 $\mathrm{nm}$. Sample solution $(0.1 \mathrm{~mL})$ and methanolic DPPH (1.9 
$\mathrm{mL}$ ) were mixed and left in the dark for $30 \mathrm{~min}$. The decrease in absorbance was measured at $515 \mathrm{~nm}$ against methanol as a blank. The results were expressed as $\mu$ mol of Trolox equivalents per gram of dry plant material ( $\mu \mathrm{mol} \mathrm{TE} / \mathrm{g}$ plant) and per gram of extract $(\mu \mathrm{mol} \mathrm{TE} / \mathrm{g}$ extract) using the standard curve of Trolox.

\section{Trolox equivalent antioxidant capacity (TEAC) assay}

Determination of the antioxidant activity with $\mathrm{ABTS}^{\cdot+}$ reagent (2,2'-azinobis (3-ethylbenzothiazoline-6sulphonic acid) diammonium salt) was carried out following the method of Thaipong, et al. (2006). The $\mathrm{ABTS}^{\cdot+}$ reagent was freshly prepared by mixing equal parts of the ABTS $(7 \mathrm{mM})$ stock solution and $\mathrm{K}_{2} \mathrm{~S}_{2} \mathrm{O}_{8}$ ( $2.45 \mathrm{mM}$ ) solution. The mixture was left for $12 \mathrm{~h}$ in the dark before use. Immediately before use, the $\mathrm{ABTS}^{\circ+}$ solution was diluted to the absorbance of $\mathrm{A}=1.1 \pm 0.02$ at $734 \mathrm{~nm}$. Sample solution $(0.1 \mathrm{~mL})$ was mixed with the ABTS $^{\circ+}$ radical solution $(1.9 \mathrm{~mL})$ and left to stand for 10 minutes (Olszewska and Michel, 2009). The decrease in absorbance was measured at $734 \mathrm{~nm}$ against methanol as a blank. The results were expressed as $\mu$ mol of TE per gram of dry plant material ( $\mu \mathrm{mol} \mathrm{TE} / \mathrm{g}$ plant) and per gram of extract ( $\mu \mathrm{mol} \mathrm{TE} / \mathrm{g}$ extract) using the standard curve of Trolox.

\section{Ferric reducing antioxidant power (FRAP) assay}

A modified FRAP method was used to determine antioxidant activity as described by Thaipong, et al. (2006). FRAP reagent was prepared immediately before use by mixing acetate buffer (300 mM, pH=3.6), $10 \mathrm{mM}$ TPTZ (2,4,6-tri(2-pyridyl)-s-triazine) in $40 \mathrm{mM} \mathrm{HCl}$ and $\mathrm{FeCl}_{3}(20 \mathrm{mM})$ in a volume ratio of 10:1:1. Sample solution $(0.1 \mathrm{~mL})$ was added to FRAP reagent $(1.9 \mathrm{~mL})$ in a test tube. The samples were incubated for $2 \mathrm{~h}$ at $37^{\circ} \mathrm{C}$ on a water bath (Olszewska and Michel, 2009) before measurements. Absorption of the blue-coloured complex was measured at $593 \mathrm{~nm}$ against a blank. The results were expressed as $\mu \mathrm{mol}$ of TE per gram of dry plant material ( $\mu \mathrm{mol} \mathrm{TE} / \mathrm{g}$ plant) and per gram of extract $(\mu \mathrm{mol} \mathrm{TE} / \mathrm{g}$ extract) using the standard curve of Trolox.

\section{Statistical analysis}

All measurements were made in triplicate, and the results were expressed as the mean \pm standard deviation (SD). Data were subjected to one-way analysis of variance followed by Duncan's multiple range test to separate the mean values. Statistical analysis was performed using IBM SPSS Statistics, version 20 (IBM Corp., Armonk, NY). The differences were considered statistically significant at $\mathrm{p}<0.05$. The correlations between the contents of tested compounds and the antioxidant activity were determined by a linear regression method (Excel, Windows 10).

\section{RESULTS AND DISCUSSION}

Leaf and fruit extracts of the investigated Sorbus species were prepared by ultrasound extraction, and extraction yields were determined and presented in Table 1.

Table 1: Yields of extracts for Sorbus leaf and fruit samples

\begin{tabular}{lcccc}
\hline Plant species & $\begin{array}{c}\text { Plant } \\
\text { part }\end{array}$ & $\begin{array}{c}\text { Mass of the } \\
\text { sample (g) }\end{array}$ & $\begin{array}{c}\text { Mass of the } \\
\text { extract (g) }\end{array}$ & $\begin{array}{c}\text { Yield } \\
\text { (\%) }\end{array}$ \\
\hline \multirow{2}{*}{ S. aria } & L & 0.5002 & 0.0182 & 36.40 \\
& F & 0.5000 & 0.0352 & 70.40 \\
S. austriaca & L & 0.5001 & 0.0163 & 32.60 \\
& F & 0.5000 & 0.0242 & 48.40 \\
S. aucuparia & L & 0.5000 & 0.0176 & 35.20 \\
& F & 0.5002 & 0.0369 & 73.80 \\
\hline
\end{tabular}

*L-leaves; F-fruit

The yields ranged from 48.40 to $73.80 \%$ for fruit samples, and from 32.60 to $36.40 \%$ for leaf samples. The highest yield was from $S$. aucuparia fruit, while the lowest yield was from $S$. austriaca leaves. It can be concluded that the extraction efficiency is higher for the fruit than the leaves. Similar observations were obtained in the study on the effects of extraction of Prunus laurocerasus leaves and fruit. Differences in extraction yields could be attributed to the presence of different compounds in each part of the plant as well as the solvent extraction activity (Karabegović, Stojičević, Veličković, et al., 2014 and references therein).

The total phenolics, flavonoids and phenolic acids contents expressed as mg of standard equivalents per gram of dry plant/extract are given in Table 2. In leaf samples, the total phenolics ranged from 30.40 to 76.11 mg GAE/g plant, flavonoids from 10.94 to $15.86 \mathrm{mg}$ RE/g plant, phenolic acids from 18.82 to $44.54 \mathrm{mg}$ $\mathrm{CAE} / \mathrm{g}$ plant. In fruit samples, determined values varied from 7.02 to $13.21 \mathrm{mg} \mathrm{GAE} / \mathrm{g}$ plant for phenolics, from 0.87 to $1.82 \mathrm{mg} \mathrm{RE} / \mathrm{g}$ plant for flavonoids and from 4.21 to $9.05 \mathrm{mg}$ CAE/ g plant for phenolic acids.

Table 2: Total phenolics, total flavonoids and total phenolic acids in Sorbus leaf and fruit samples.

\begin{tabular}{cccccccc}
\hline \multirow{2}{*}{ Species } & \multirow{2}{*}{ Sample } & \multicolumn{2}{c}{ Total phenolics } & \multicolumn{2}{c}{ Total flavonoids } & \multicolumn{2}{c}{ Total phenolic acids } \\
\cline { 3 - 8 } & & $\begin{array}{c}\text { mg GAE/g } \\
\text { plant }\end{array}$ & $\begin{array}{c}\text { mg GAE/g } \\
\text { extract }\end{array}$ & $\begin{array}{c}\text { mg RE/g } \\
\text { plant }\end{array}$ & $\begin{array}{c}\text { mg RE/g } \\
\text { extract }\end{array}$ & $\begin{array}{c}\text { mg CAE/g } \\
\text { plant }\end{array}$ & $\begin{array}{c}\text { mg CAE/g } \\
\text { extract }\end{array}$ \\
\hline \multirow{2}{*}{ S. aria } & Leaves & $55.93 \pm 0.00^{\mathrm{e}}$ & $153.71 \pm 0.00^{\mathrm{d}}$ & $10.94 \pm 0.43^{\mathrm{c}}$ & $30.08 \pm 1.20^{\mathrm{c}}$ & $33.80 \pm 0.18^{\mathrm{d}}$ & $92.90 \pm 0.50^{\mathrm{e}}$ \\
& Fruit & $7.02 \pm 0.02^{\mathrm{a}}$ & $9.97 \pm 0.03^{\mathrm{a}}$ & $0.92 \pm 0.03^{\mathrm{a}}$ & $1.31 \pm 0.05^{\mathrm{a}}$ & $4.21 \pm 0.04 \mathrm{a}$ & $5.98 \pm 0.06^{\mathrm{a}}$ \\
\hline \multirow{2}{*}{ S. austriaca } & Leaves & $76.11 \pm 2.70^{\mathrm{f}}$ & $233.54 \pm 8.30^{\mathrm{e}}$ & $15.86 \pm 0.32^{\mathrm{e}}$ & $48.66 \pm 0.97^{\mathrm{e}}$ & $44.54 \pm 0.65^{\mathrm{e}}$ & $136.70 \pm 2.01^{\mathrm{f}}$ \\
& Fruit & $13.21 \pm 0.26^{\mathrm{c}}$ & $27.29 \pm 0.54^{\mathrm{b}}$ & $1.82 \pm 0.01^{\mathrm{b}}$ & $3.76 \pm 0.02^{\mathrm{b}}$ & $8.94 \pm 0.05^{\mathrm{b}}$ & $18.47 \pm 0.10^{\mathrm{c}}$ \\
\hline \multirow{2}{*}{ S. } & Leaves & $30.40 \pm 0.04^{\mathrm{d}}$ & $86.33 \pm 0.11^{\mathrm{c}}$ & $14.01 \pm 0.15^{\mathrm{d}}$ & $39.81 \pm 0.43^{\mathrm{d}}$ & $18.82 \pm 0.10^{\mathrm{c}}$ & $53.48 \pm 0.28^{\mathrm{d}}$ \\
aucuparia & Fruit & $10.13 \pm 0.05^{\mathrm{b}}$ & $13.74 \pm 0.07^{\mathrm{a}}$ & $0.87 \pm 0.01^{\mathrm{a}}$ & $1.18 \pm 0.02^{\mathrm{a}}$ & $9.05 \pm 0.06^{\mathrm{b}}$ & $12.27 \pm 0.08^{\mathrm{b}}$ \\
\hline Values with
\end{tabular}

Values with different upper-case letters in the same column are significantly different at $\mathrm{p}<0.05$ 
Sorbus austriaca leaves had significantly higher $(\mathrm{p}<0.05)$ contents of all bioactive compounds. In general, the reported values of Olszewska and Michel (2009), Olszewska (2010, 2011) and Gaivelyte, et al. (2014), for total phenolics in S. aucuparia leaves (7.079.09\% dry weight(DW)), are higher than in this work, and for flavonoids (0.038-1.58\% DW) and phenolic acids $(0.97-3.90 \% \mathrm{DW})$ they are comparable to the results of this study. Olszewska and Michel (2009) reported a higher content of phenols (6.06\% DW) and flavonoids $(1.30 \% \mathrm{DW})$ but lower content of phenolic acids $(1.73 \% \mathrm{DW})$ in $S$. aria leaves than those given in this work. Sorbus austriaca fruit had the highest contents of phenolics and flavonoids. However, no significant difference was determined in the values of phenolic acids content between S. austriaca and S. aucuparia fruit.

In general, data for $S$. austriaca are quite limited. Raudoné, et al. (2015) reported similar values for total phenolic acids content between S. aucuparia $(0.283 \%$ DW) and S. austriaca fruit $(0.286 \%$ DW). Values for total flavonoids in S. austriaca fruit $(0.0143 \% \mathrm{DW})$ and phenolic acids $(0.286 \% \mathrm{DW})$ given by Raudonis, et al. (2014) were lower than the results in this study. In addition, there was no significant difference $(p<0.05)$ in the values of total flavonoids content between the fruit of S. aucuparia and S. aria. According to Olszewska and Michel (2009) and Šavikin, et al. (2017), contents of phenolics, flavonoids and phenolic acids in S. aucuparia fruit yielded up to $2.68 \%, 0.104 \%$ and $1.52 \%$, while for S. aria fruit they varied up to $2.98 \%, 0.093 \%$ and $0.63 \%$, respectively. In general, the leaves have significantly higher $(\mathrm{p}<0.05)$ contents of all bioactive compounds in relation to the fruit which is in agreement with the findings of Olszewska and Michel (2009), Gaivelyte, et al. (2014 and references therein). Differences found between our results and previous investigations could be due to genetic factors, environmental conditions, maturity and time of harvest (Olszewska, 2011; Gaivelyte et al., 2014 and references therein). It is important to emphasize that the extraction method and extraction medium could influence the differences as reported by Olsezwska, Presler, Michel, et al. (2012), Aladedunye and Matthäus (2014). In addition, the phenolics content for $S$. austriaca and $S$. aria leaves are close to that of Crataegus monogyna (61.98 mg GAE/g DW), Crataegus x macrocarpa (82.44 mg GAE/g DW) (Tahirović and Bašić, 2015) and Aloe littoralis (62.00 mg GAE/g DW) (Surweswaran, et al., 2007). The values are higher than those reported for Artemisia abrotanum
(4.9 mg GAE/g DW), Euphorbia lathyrus (11.50 mg GAE/g DW) and Ocimum basilicum (26.30 mg GAE/g DW) by Surweswaran, et al. (2007). On the other hand, the content of phenolics in fruit is much lower than in Prunus spinosa (25.14 mg GAE/g DW), Crataegus monogyna (28.19 mg GAE/g DW), Rosa canina (51.19 mg GAE/g DW) extracted with the same extraction medium (Tahirović, Bašić, Čopra-Janićijević, et al., 2018; Tahirović and Bašić, 2015, 2017). In general, phenolics content in leaves of S. austriaca and S. aria were higher than $5 \%$, so we can conclude on the basis of data and references given by Olszewska and Michel (2009) that leaves of these species represent a rich source of phenolic compounds. The results expressed per gram of extracts for leaves ranged from 86.33 to 233.54 mg GAE/g extract for phenolics, from 30.08 to $48.66 \mathrm{mg}$ RE/g extract for flavonoids and from 53.48 to $136.70 \mathrm{mg}$ $\mathrm{CAE} / \mathrm{g}$ extract for total phenolic acids. For fruit samples, obtained values were in the range of 9.97-27.29 mg GAE/g extract for phenolics, 1.18-3.76 mg RE/g extract for flavonoids and 5.98-18.47 mg CAE/g extract for phenolic acids (Table 2). Sorbus austriaca is the species with the highest content of investigated bioactive compounds in leaves and fruit. In addition, there are no significant differences $(p<0.05)$ in the contents of total phenolics and flavonoids for S. aria and S. aucuparia fruit samples. Mrkonjić et al. (2017) reported for $S$. aucuparia fruit values of $0.187 \mathrm{mg} / \mathrm{g}$ extract for total flavonoids and $0.0154 \mathrm{mg} / \mathrm{g}$ extract for phenolic acids, which is lower than the data in this study. Results of total phenolics for butanol and ethyl acetate extracts of S. aucuparia fruit (42-103 $\mathrm{mg} / \mathrm{g}$ extract) given by Aladedunye and Matthäus (2014) were generally higher. The content of phenolics in fruit was lower than values reported for cherry laurel (42.2 mgGAE/g extract; Karabegović, et al., 2014), rosehips (149.35 mg GAE/g extract; Barros, Carvalho, Ferreira, et al., 2011) and hawthorn (274.27 mg GAE/g extract; Barros, Carvalho, Ferreira, et al., 2011).

\section{Antioxidant activity}

The DPPH, TEAC and FRAP assays were performed to assess the antioxidant activity of leaf and fruit extracts. The obtained results are expressed as $\mu \mathrm{mol} \mathrm{TE} / \mathrm{g}$ plant and $\mu \mathrm{mol} \mathrm{TE} / \mathrm{g}$ extract and shown in Table 3 . Antioxidant activity of Sorbus leaf samples ranged from 121.80 to $274.52 \mu \mathrm{mol} \mathrm{TE} / \mathrm{g}$ plant for $\mathrm{DPPH}$, from 142.52 to $403.02 \mu \mathrm{mol} \mathrm{TE} / \mathrm{g}$ plant for TEAC, and from 287.03 to $706.96 \mu \mathrm{mol} \mathrm{TE} / \mathrm{g}$ plant for FRAP method.

Table 3: Antioxidant activity of Sorbus species leaf and fruit samples determined by DPPH, ABTS and FRAP methods

\begin{tabular}{|c|c|c|c|c|c|c|c|}
\hline \multirow[b]{2}{*}{ Species } & \multirow[b]{2}{*}{ Sample } & \multicolumn{2}{|c|}{ DPPH } & \multicolumn{2}{|c|}{ TEAC } & \multicolumn{2}{|c|}{ FRAP } \\
\hline & & $\begin{array}{c}\mu \mathrm{mol}(\mathrm{TE}) / \mathrm{g} \\
\text { plant }\end{array}$ & $\begin{array}{c}\mu \mathrm{mol}(\mathrm{TE}) / \mathrm{g} \\
\text { extract }\end{array}$ & $\begin{array}{c}\mu \mathrm{mol}(\mathrm{TE}) / \mathrm{g} \\
\text { plant }\end{array}$ & $\begin{array}{c}\mu \mathrm{mol}(\mathrm{TE}) / \mathrm{g} \\
\text { extract }\end{array}$ & $\begin{array}{c}\mu \mathrm{mol}(\mathrm{TE}) / \mathrm{g} \\
\text { plant }\end{array}$ & $\begin{array}{c}\mu \mathrm{mol}(\mathrm{TE}) / \mathrm{g} \\
\text { extract }\end{array}$ \\
\hline \multirow{2}{*}{ S. aria } & Leaves & $234.92 \pm 0.90^{\mathrm{e}}$ & $645.70 \pm 2.41^{\mathrm{e}}$ & $364.63 \pm 2.42^{\mathrm{e}}$ & $1002.13 \pm 6.64^{\mathrm{e}}$ & $551.94 \pm 0.33^{\mathrm{e}}$ & $1516.93 \pm 0.90^{\mathrm{e}}$ \\
\hline & Fruit & $17.90 \pm 0.09^{\mathrm{a}}$ & $101.63 \pm 0.51^{\mathrm{a}}$ & $43.23 \pm 0.53^{\mathrm{a}}$ & $61.40 \pm 0.75^{\mathrm{a}}$ & $47.13 \pm 0.08^{\mathrm{a}}$ & $66.95 \pm 0.11^{\mathrm{a}}$ \\
\hline \multirow{2}{*}{$\begin{array}{c}S . \\
\text { austriaca }\end{array}$} & Leaves & $274.52 \pm 5.30^{f}$ & $842.24 \pm 16.14^{\mathrm{f}}$ & $403.02 \pm 6.81^{\mathrm{f}}$ & $1236.51 \pm 20.90^{\mathrm{f}}$ & $706.96 \pm 29.82^{f}$ & $2169.03 \pm 91.50^{f}$ \\
\hline & Fruit & $61.26 \pm 1.40^{c}$ & $506.30 \pm 11.30^{d}$ & $82.90 \pm 1.81^{\mathrm{c}}$ & $171.18 \pm 3.75^{c}$ & $138.06 \pm 0.10^{c}$ & $285.24 \pm 0.21^{\mathrm{c}}$ \\
\hline \multirow{2}{*}{$\begin{array}{c}\text { S. } \\
\text { aucuparia }\end{array}$} & Leaves & $121.80 \pm 0.80^{\mathrm{d}}$ & $346.02 \pm 2.30^{c}$ & $142.52 \pm 2.34^{\mathrm{d}}$ & $404.90 \pm 6.64^{\mathrm{d}}$ & $287.03 \pm 0.32^{\mathrm{d}}$ & $815.41 \pm 0.92^{\mathrm{d}}$ \\
\hline & Fruit & $38.42 \pm 0.72^{b}$ & $208.32 \pm 3.90^{\mathrm{b}}$ & $67.64 \pm 1.70^{\mathrm{b}}$ & $91.70 \pm 2.24^{b}$ & $101.10 \pm 0.70^{\mathrm{b}}$ & $137.04 \pm 1.30^{\mathrm{b}}$ \\
\hline
\end{tabular}

Values with different upper-case letters in the same column are significantly different at $\mathrm{p}<0.05$ 
Sorbus fruit samples gave results ranging from 17.90 to $61.26 \mu \mathrm{mol} \mathrm{TE} / \mathrm{g}$ for DPPH, from 43.23 to $82.90 \mu \mathrm{mol}$ TE/g plant for TEAC and from 47.13 to $138.06 \mu \mathrm{mol}$ TE/g plant for FRAP. The leaves revealed significantly higher $(\mathrm{p}<0.05)$ antioxidant properties than those of fruit samples. The results agree with those observed by Cyboran, Bonarska-Kujawa, Pruchnik (2014) and Olszewska and Michel (2009). Sorbus austriaca leaf and fruit samples showed significantly higher $(\mathrm{p}<0.05)$ antioxidant activity in the DPPH, TEAC, and FRAP assays.

The values of antioxidant activity decreased in the order: S. austriaca $>S$. aria $>S$. aucuparia leaves, and in the order: S. austriaca $>$ S. aucuparia $>$ S. aria fruit. Olszewska and Michel (2009) demonstrated that leaves of $S$. aucuparia have higher antioxidant activity than $S$. aria, but fruit of $S$. aria have higher antioxidant activity than S. aucuparia. These results could be associated with the quantitative contents of investigated compounds in the sample. The results in this study for S. austriaca leaves and fruit were higher than that of Raudoné, et al. (2015) for $S$. austrica leaves (FRAP $=78.29 \mu \mathrm{mol} \mathrm{TE} / \mathrm{g}$ DW) and of Raudonis, et al. (2014) for $S$. austrica fruit (TEAC $=9.70 \mu \mathrm{mol}$ TE/g DW; FRAP $=9.58 \mu \mathrm{mol} \mathrm{TE} / \mathrm{g}$ DW). The results of antioxidant activity given by Raudoné, et al., (2015), Olszewska and Michel (2009), Olszewska et al. (2011) for S. aucuparia leaf (FRAP=144.31-1650 $\mu \mathrm{mol} \mathrm{TE} / \mathrm{g} \quad \mathrm{DW})$ and fruit (ABTS=11.19-91.6; FRAP=11.83-347 $\mu \mathrm{mol}$ TE/g DW) and $S$. aria leaf $(\mathrm{ABTS}=265.5 \mu \mathrm{mol} \mathrm{TE} / \mathrm{g} \quad \mathrm{DW}$; FRAP $=136.53-861.6 \mu \mathrm{mol} \mathrm{TE} / \mathrm{g} \mathrm{DW})$ samples were in agreement with the results in this study. However, values of $\mathrm{DPPH}=400-628 \mu \mathrm{mol} \mathrm{TE} / \mathrm{g} \mathrm{DW}$ for $S$. aucuparia leaves, collected in summer, were also reported (Olszewska and Michel, 2009, Olszewska, 2011). In general, the antioxidant activity of $S$. aria fruit was lower than the values given by Olszewska and Michel (2009). The differences can be explained in the same way as described for the phenolic content. In addition, antioxidant activity of investigated Sorbus fruit samples had lower values than blackthorn fruit (118.37-193.19 $\mu \mathrm{mol} \mathrm{TE} / \mathrm{g} \mathrm{DW})$, rosehip fruit (278.34-422.16 $\mu \mathrm{mol}$ TE/g DW), hawthorn species (0.11-0.51 mmol TE/g DW) determined by DPPH, TEAC and FRAP methods in 80\% methanol extracts (Tahirović, et al., 2018; Tahirović and Bašić, 2015, 2017). According to Surweswaran et al. (2007), antioxidant activity with TEAC values between 50.10 and $1000 \mu \mathrm{g}$ TE/g DW is considered as high. We can conclude that leaves of Sorbus species have high antioxidant activity, while the fruit have a medium antioxidant activity.

The antioxidant activity of Sorbus leaves, expressed as $\mu \mathrm{mol} \mathrm{TE} / \mathrm{g}$ of the extracts, ranged from 346.02 to 842.24 $\mu \mathrm{mol} \mathrm{TE} / \mathrm{g}$ extract for DPPH, from 404.90 to 1236.15 $\mu \mathrm{mol} \mathrm{TE} / \mathrm{g}$ extract for TEAC and from 815.41 to $2169.03 \mu \mathrm{mol}$ (TE)/g extract for FRAP assay (Table 3). The results for Sorbus fruit samples varied from 101.63 to $506.30 \mu \mathrm{mol} \mathrm{TE} / \mathrm{g}$ extract for $\mathrm{DPPH}$, from 61.40 to $171.18 \mu \mathrm{mol} \mathrm{TE} / \mathrm{g}$ extract for TEAC and from 66.95 to $285.24 \mu \mathrm{mol} \mathrm{TE} / \mathrm{g}$ extract for FRAP assay. It should be mentioned that FRAP values of leaves are higher than those of DPPH and TEAC assay (Table 3). Vitamin C contributes significantly to the reduction properties of extracts, and its quantity in extracts of some Sorbus species was determined by several researchers (Egea, et al., 2010 and references therein). The higher reduction capability could be attributed to the higher levels of strong reductants capable of donating electrons (Sasikumar, Patharaj, Adithya, et al., 2012).

Correlation coefficients were investigated among the total phenolics, flavonoids, phenolic acids, and antioxidant activity with a linear regression method. The obtained results are presented in Table 4 . The total phenols $\left(r^{2}=0.7761-0.9981\right)$ and total phenolic acids $\left(r^{2}=0.7672-0.9969\right)$ are highly correlated with DPPH, TEAC and FRAP activity. Correlations between total flavonoids $\left(r^{2}=0.3984-0.7974\right)$ and antioxidant activity were lower. Higher correlation coefficients are probably associated with higher total phenolics and phenolic acids content of the samples (Table 2). Several studies suggest that phenolic compounds, including phenolic acids, can contribute to the antioxidant activity. The results obtained here were consistent with the results of other researchers confirming the correlations between different phenolic compounds and antioxidant activity (Olszewska and Michel, 2009; Raudonis et al., 2014; MikulićPetkovsek, et al., 2017; Šavikin et al., 2017).

Table 4: Correlation coefficients between phenolics, flavonoids, phenolic acids and antioxidant activity Correlations for data expressed in (mg/g plant)

\begin{tabular}{cccc} 
Bioactive compounds & DPPH & $\begin{array}{c}\text { TEAC } \\
\text { FRAP }\end{array}$ \\
\hline Phenolics & 0.985 & 0.9678 & 0.9965 \\
Flavonoids & 0.7529 & 0.6470 & 0.7488 \\
Phenolic acids & 0.9856 & 0.9703 & 0.9969 \\
\hline & \multicolumn{3}{c}{ Correlations for data expressed in } \\
& DPPH $/$ g extract) & TEAC & FRAP \\
\hline Phenolics & 0.7761 & 0.9753 & 0.9981 \\
Flavonoids & 0.3984 & 0.716 & 0.7974 \\
Phenolic acids & 0.7672 & 0.9775 & 0.9990 \\
\hline
\end{tabular}

\section{CONCLUSIONS}

The most abundant phenolic compounds in the investigated Sorbus species are total phenolics and phenolic acids, while the content of total flavonoids was lower. Sorbus austriaca leaves and fruit had a significantly higher $(\mathrm{p}<0.05)$ content of active compounds than other species, except the total phenolic acids in fruit. However, no significant difference $(p<0.05)$ was found in the phenolic acids content between $S$. austriaca and $S$. aucuparia fruit. In addition, $S$. austriaca leaf and fruit extracts had significantly higher antioxidant activity than extracts of other species. In general, the leaf samples have a significantly higher content of bioactive compounds and antioxidant activity than the fruit samples. Based on the results obtained in this study, we can conclude that the investigated Sorbus species, in particular, S. austriaca, represent a valuable source of natural antioxidants with the possibility of their application in medicine, pharmacy and the food industry. In this regard, more detailed investigations on the quantitative composition of individual phenolic compounds and their antioxidant properties are necessary. 


\section{REFERENCES}

Aladedunye, F., Matthäus, B. (2014). Phenolic extracts from Sorbus aucuparia (L.) and Malus baccata (L.) berries: antioxidant activity and performance in rapeseed oil during frying and storage. Food Chemistry, 159, 273-281.

Barros, L., Carvalho, A.M., Ferreira, I.C. F.R. (2011). Exotic fruit as a source of important phytochemicals. Improving the traditional use of Rosa canina fruits in Portugal. Food Research International, 44, (7), 2233-2236.

Barros, l., Carvalho, A.M., Ferreira, I.C. (2011). Comparing the composition and bioactivity of Crataegus monogyna flowers and fruits used in folk medicine. Phytochemical Analysis, 22, 181188.

Beck-Mannagetta, G. (1927). Flora Bosne, Hercegovine i oblasti Novog Pazara, III. Horipetale. Državna štamparija u Sarajevu, Beograd-Sarajevo, 184.

Cyboran, S., Bonarska-Kujawa, D., Pruchnik, H., Zyłka, R., Oszmianski, J., Kleszczynska, H. (2014). Phenolic content and biological activity of extracts of blackcurrant fruit and leaves. Food Research International, 65, Part A, 47-58.

Egea, I., Sánchez-Bel, P., Romojaro, F., Pretel, M.T. (2010). Six edible wild fruits as potential antioxidant additives or nutritional supplements. Plant Foods for Human Nutrition, 65, (2), 121129

Finley, J.W., Kong, A-N., Hintze, K.J., Jeffery, E.H., Ji, L.L., Lei, X.G. (2011). Antioxidants in foods: state of the science important to the food industry. Journal of Agricultural and Food Chemistry, 59, (13), 6837-6846.

Gaivelyte, K., Jakstas, V., Razukas, A., Janulis, V. (2014). Variation of quantitative composition of phenolic compounds in rowan (Sorbus aucuparia L.) leaves during the growth season. Natural Product Research, 28(13), 1018-1020.

Gawlic-Dziki, U. (2012). Changes in the antioxidant activities of vegetables as a consequence of interactions between active compounds. Journal of Functional Foods, 4 (4), 872-882

Hajrudinović, A., Siljak-Yakovlev, S., Brown, S.C., Pustahija, F., Bourge, M., Ballian, D., Bogunić, F. (2015b). When sexual meets apomict: genome size, ploidy level and reproductive mode variation of Sorbus aria s.l. and S. austriaca (Rosaceae) in Bosnia and Herzegovina. Annals of Botany, 116 (2): 301-312.

Hukkanen, A. T., Pölönen, S. S., Kärenlampi, S. O., Kokko, H. I. (2006). Antioxidant capacity and phenolic content of sweet rowanberries. Journal of Agricultural Food Chemistry, 54, (1), 112-119.

Karabegović, I.T., Stojičević, S.S., Veličković, D.T., Todorović, Z.B., Nikolić, N.Č., Lazić, M.L. (2014). The effect of different extraction techniques on the composition and antioxidant activity of cherry laurel (Prunus laurocerasus) leaf and fruit extracts. Industrial Crops and Products, 54, 142-148.
Luthria, D.L., Mukhopadhyay S., Krizek, D.T. (2006). Content of total phenolics and phenolic acids in tomato (Lycopersicon esculentum Mill.) fruits as influenced by cultivar and solar UV radiation. Journal of Food Composition and Analysis, 19, 771-777.

Memon, A., Memon, N., Luthria, D.L., Bhanger, M. I., Pitafi, A. A. (2010). Phenolic acids profiling and antioxidant potential of mulberry (Morus laevigata W., Morus nigra L., Morus alba L.). Leaves and fruits grown in Pakistan. Polish Journal of Food and Nutrition Sciences, (1), 2532

Mikulić-Petkovsek, M., Krska, B., Kiprovski, B., Veberic, R. (2017). Bioactive components and antioxidant capacity of fruits from nine Sorbus genotypes. Journal of Food Science, 82(3), 647658.

Mrkonjić, Z., Nađpal, J., Beara, I., Sabo, V. A., Četojević-Simin, D., Mimica-Dukić, N., Lesjak, M. (2017). Phenolic profiling and bioactivities of fresh fruits and jam of Sorbus species. Journal of Serbian Chemical Society, 82(6), 651-664.

Olszewska, M.A., Michel, P. (2009). Antioxidant activity of inflorescences leaves and fruits of three Sorbus species in relation to their polyphenolic composition. Natural Product Research, 23, (16), 1507-1521.

Olszewska, M.A., Nowak, S., Michel, P., Banaszczak, P., Kicel, A. (2010). Assessment of the content of phenolics and antioxidant action of inflorescences and leaves of selected species from the genus Sorbus sensu stricto. Molecules, 15, (12), 87698783.

Olszewska, M.A. (2011). Variation in the phenolic content and in vitro antioxidant activity of Sorbus aucuparia leaf extracts during vegetation. Acta Poloniae Pharmaceutica, 68, (6), 937-944.

Olszewska, M. A., Presler, A., Michel, P. (2012). Profiling of phenolic compounds and antioxidant activity of dry extracts from the selected Sorbus species. Molecules, 17(3), 3093-3113.

Quettier-Deleu, C., Gressier, B., Vasseur J., Dine T., Brunet C., Luyckx M.C., Cazin M., Cazin, J.C., Bailleul F., Trotin F. (2000). Phenolic compounds and antioxidant activities of buckwheat (Fagopyrum esculentum Moench) hulls and flour. Journal Ethnopharmacology, 72, (1-2), 35-42.

Raudoné, L., Raudonis, R., Gaivelyte, K., Pukalskas, A., Viškelis, P., Venskutonis, P. R., Janulisa, V. (2015). Phytochemical and antioxidant profiles of leaves from different Sorbus L. Species. Natural Product Research,. 29 (3), 281-285

Raudonis, R., Raudoné L., Gaivelyte, K., Višelis, P., Janulis, V. (2014). Phenolic and antioxidant profiles of rowan (Sorbus L.) fruits. Natural Product Research, 28 (16), 1231-1240. 
Sasikumar, J. M., Patharaj, J., Adithya, E. S., Christabel, P. H., Shamna, R. (2012). Antioxidant capacity and phenolic content of Elaeagnus kologa schlecht. An underexploited fruit from India. Free Radicals and Antioxidants, 2(3), 28-35.

Surveswaran, S., Cai, Y-Z., Corke, H. Sun, M. (2007). Systematic evaluation of natural phenolic antioxidants from 133 Indian medicinal plants. Food Chemistry, 102, (3), 938-953.

Šavikin, K. P., Zdunić, G. M., Krstić-Milošević, D. B., Šircelj, H. J., Stešević, D. D., Pljevljakušić, D. S. (2017). Sorbus aucuparia and Sorbus aria as a Source of Antioxidant Phenolics, Tocopherols, and Pigments. Chemistry and Biodiversity, 14(12).

Tahirović, A., Bašić, N. (2015). Phenolic content and antioxidant activity of Crataegus monogyna Jacq. and Crataegus macrocarpa Hegetscw. leaves and fruits extracts. Works of the Faculty of Forestry University of Sarajevo, 45(2) 37-51.
Tahirović, A., Bašić, N. (2017). Determination of phenolic content and antioxidant activity of Rosa canina L. fruits in different extraction systems. Works of the Faculty of Forestry University of Sarajevo, 47 (1) 47-59.

Tahirović, A., Bašić, N., Čopra-Janićijević, A. (2018). Effect of solvents on phenolic compounds extraction and antioxidant activity of Prunus spinosa L. fruits. Bulletin of the Chemists and Technologists of Bosnia and Herzegovina, 50, 1924.

Thaipong, K., Boonprakob, U., Crosby, K., CisnerosZevalos, L., Byrne, D. H. (2006). Comparison of ABTS, DPPH, FRAP, and ORAC assays for estimating antioxidant activity from guava fruit extracts. Journal of Food Compostion and Analysis, 19, 669-675.

\section{Summary/Sažetak}

Ispitivan je sadržaj fenola i antioksidacijska aktivnost lišća i plodova vrsta Sorbus aucuparia L., Sorbus aria (L.) Crantz i Sorbus austriaca (Beck) Hedlund. Kvantifikacija ukupnih fenola, flavonoida i fenolnih kiselina provedena je FolinCiocalteu, Dowd-om i Arnow-om metodom. Antioksidacijska aktivnost ekstrakata je procijenjena korištenjem DPPH, ABTS i FRAP metode s Troloxom kao standardom. Lišće je imalo veći sadržaj fenolnih spojeva i veću antioksidacijsku aktivnost od plodova za sve vrste. Najveći sadržaj fenola (76,11 mg ekvivalenata galne kiseline (GAE)/g biljke), flavonoida (15,86 mg ekvivalenata rutina (RE)/g biljke) i fenolnih kiselina (44,54 mg ekvivalenata kafene kiseline (CAE)/g biljke) utvrđen je za listove S. austriaca. Plodovi S. austriaca imali su najveći sadržaj fenola (13,21 mg GAE/g biljke) i flavonoida (1,82 mg RE/g biljke), a plodovi S. aucuparia imali su najveći sadržaj fenolnih kiselina (9,05 mg CAE /g biljke). Antioksidacijska aktivnost kretala se u području: DPPH=38,42-274,52 $\mu \mathrm{mol}$ TE/g biljke; ABTS=43,23-403,02 $\mu \mathrm{mol}$ TE/g biljke; FRAP=47,13-706,96 $\mu \mathrm{mol}$ TE/g biljke. Najveće vrijednosti antioksidacijske aktivnosti utvrđene su za ekstrakte lista i ploda $S$. austriaca, dok su najniže vrijednosti utvrđene za listove $S$. aucuparia i plodove $S$. aria. Antioksidacijska aktivnost je bila u visokoj korelaciji sa ukupnim fenolima i fenolnim kiselinama. 